\title{
STRATEGI PENINGKATAN MUTU PROGRAM PEMBERDAYAAN EKONOMI MASYARAKAT PESISIR (PEMP) DI KABUPATEN MALUKU TENGGARA
}

\author{
The Quality Improvement Strategy of Coastal Community Economy Empowerment Program (PEMP) \\ in Sub-province South East Moluccas.
}

\author{
Sitti Bulkis Bandjar 1, Lala M. Kolopaking ${ }^{2}$, dan Lukman M. Baga ${ }^{3}$ \\ ${ }^{1}$ Kepala Sub. Bagian Analisis Jabatan Sekertariat Daerah Provinsi Maluku. E-mail: mpdip@hotmail.com \\ 2 Staff Pengajar Departemen Sains Komunikasi Pengembangan Masyarakat, Fakultas Ekologi Manusia IPB. \\ E-mail: lalakolopaking@gmail.com \\ ${ }^{3}$ Staff Pengajar Departemen Agribisnis. Fakultas Ekonomi dan Manajemen IPB. \\ E-mail: lukmanmb@yahoo.com.
}

\begin{abstract}
PEMP Program in Sub-province South East Moluccas is executed since 2001-2007 expected can give positive result to coastal community and small islands especially to fisherman community. The objective of this research is evaluate the sustainable status of PEMP program and identify the performance elements that have an effect on to PEMP program execution so it can be formulated the policy strategy of marine and fisheries development of Sub-province South East Moluccas. The result of this research indicates that program performance in totally pertained "enough" based on RAPFISH analysis. Based on Analytical Hierarchy Process (AHP) result there are fourth criterions that must be paid attention that are (1) PEMP program planning base on society aspect, (2) PEMP program socialization aspect, (3) PEMP program companion execution aspect, and (4) PEMP program execution evaluation aspect. From those fourth criterions, there are five alternatives of policy strategies that ought to conducted by local government of Sub-province South East Moluccas in exploiting PEMP program, that are (1) Strategy of institute reinforcement policy PEMP and human resources, (2). Strategy fund sharing policy from Government of Sub-province South East Moluccas, (3). Strategy of community participation quality improvement policy, (4) Strategy of system structuring current fund returns policy, and (5) Strategy of partnership development policy.
\end{abstract}

Keywords: strategy, quality improvement, coastal community economy empowerment program.

\begin{abstract}
ABSTRAK
Program PEMP di Kabupaten Maluku Tenggara yang dilaksanakan sejak Tahun 2001-2007 diharapkan dapat memberikan hasil yang positif kepada masyarakat pesisir dan pulau-pulau kecil khususnya masyarakat nelayan. Tujuan penelitian ini adalah mengevaluasi status keberlanjutan program PEMP, mengidentifikasi elemen kinerja yang berpengaruh terhadap pelaksanaan program PEMP sehingga dapat dirumuskan strategi kebijakan pembangunan kelautan dan perikanan Kabupaten Maluku Tenggara. Hasil penelitian memperlihatkan bahwa kinerja program secara menyuluruh tergolong "cukup" berdasarkan hasil analisis RAPFISH. Berdasarkan hasil Analisis Hirarki Proses (AHP) terdapat 4 kriteria yang harus diperhatikan yaitu (1) aspek perencanaan program PEMP berbasis masyarakat, (2) aspek sosialisasi program PEMP, (3) aspek pelaksanaan pendampingan program PEMP, dan (4) aspek evaluasi pelaksanaan program PEMP. Dari keempat kriteria tersebut ada lima alternatif strategi kebijakan yang seharusnya dilakukan oleh Pemerintah Daerah Kabupaten Maluku Tenggara dalam memanfaatkan program PEMP, yaitu (1) Strategi kebijakan penguatan kelembagaan PEMP dan SDM, (2). Strategi kebijakan sharing dana dari Pemerintah Kabupaten Maluku Tenggara, (3) Strategi kebijakan peningkatan kualitas partisipasi masyarakat, (4) Strategi kebijakan penataan sistem pengembalian dana bergulir, dan (5) Strategi kebijakan pengembangan kemitraan.
\end{abstract}

Kata kunci: strategi, peningkatan mutu, program pemberdayaan ekonomi masyarakat pesisir.

Sitti Bulkis Bandjar, Lala M. Kolopaking,

dan Lukman M. Baga
Strategi Peningkatan Mutu Program Pemberdayaan Ekonomi Masyarakat Pesisir (PEMP) di Kabupaten Maluku Tenggara 


\section{PENDAHULUAN}

\section{Latar Belakang}

Kabupaten Maluku Tenggara merupakan salah satu kabupaten kepulauan yang ada di Provinsi Maluku dengan 112 buah pulau dimana hampir seluruhnya merupakan pulau-pulau kecil, memiliki potensi sumberdaya kelautan dan perikanan yang cukup melimpah. Luas wilayah administratif Kabupaten ini adalah $34.821,4 \mathrm{~km}^{2}$ dengan luas lautan $30.772,4$ $\mathrm{km}^{2}(88,37 \%)$ dan luas daratan hanya $4.049 \mathrm{~km}^{2}(11,63 \%)$ atau dengan kata lain luas lautannya adalah 7,6 kali luas daratannya. Sebagian besar penduduk Kabupaten Maluku Tenggara bertempat tinggal di wilayah pesisir dan pulau-pulau kecil, sehingga dengan demikian mata pencaharian utama masyarakatnya adalah sebagai nelayan (DKP, 2006).

Berbicara tentang masyarakat pesisir, tidak akan terlepas dari masalah masyarakat nelayan karena sebagian besar penduduk daerah pesisir umumnya memiliki mata pencaharian sebagai nelayan (Satria et al, 2002). Masyarakat pesisir didefinisikan sebagai kelompok orang yang tinggal di daerah pesisir dan sumber kehidupan perekonomiannya bergantung secara langsung pada pemanfaatan sumberdaya laut dan pesisir (Nikijuluw, 2001).

Sebagian besar penduduk yang hidup di wilayah pesisir dan pulau-pulau kecil di Kabupaten Maluku Tenggara saat ini masih tergolong berada dibawah garis kemiskinan bila dibandingkan dengan penduduk lainnya, padahal wilayah pesisir dan pulau-pulau kecil adalah kawasan yang secara hayati sangat produktif. Kemiskinan, rendahnya pendidikan dan pengetahuan serta kurangnya informasi sebagai akibat keterisolasian pulau-pulau kecil merupakan karakteristik dari masyarakat pulau-pulau kecil (Sulistyowati, 2003).

Dalam upaya untuk meningkatkan kesejahteraan masyarakat pesisir di
Kabupaten Maluku Tenggara, maka penyusunan program pembangunan perlu melibatkan masyarakat setempat. Keterlibatan masyarakat dalam program pembangunan sangatlah penting karena akan membentuk sikap positif terhadap program yang akan dilaksanakan (Nikijuluw, 2001).

Salah satu program yang telah dikembangkan dengan berbasis pada masyarakat adalah program PEMP. Program PEMP merupakan kebijakan Departemen Kelautan dan Perikanan yang sejak tahun 2000 dilaksanakan untuk memenuhi kebutuhan masyarakat pesisir dalam rangka meningkatkan kesejahteraan masyarakat. Secara umum program PEMP bertujuan meningkatkan kesejahteraan masyarakat pesisir melalui pengembangan kultur kewirausahaan, penguatan Lembaga Keuangan Mikro (LKM), penggalangan partisipasi masyarakat dan kegiatan usaha ekonomi serta kegiatan ekonomi produktif lainnya yang berbasis sumberdaya lokal dan berkelanjutan (DKP, 2006).

Untuk Provinsi Maluku, program ini baru dilaksanakan pada tahun 2001 dan tersebar pada delapan kabupaten/kota. Khusus untuk Kabupaten Maluku Tenggara, jumlah DEP yang telah disalurkan sejak tahun 2001-2007 adalah sebesar Rp 3.821.975.000,- untuk 115 Kelompok Masyarakat Pemanfaat (KMP) dengan jenis usahanya adalah Penangkapan ikan, Kios Bahan Bakar Minyak (BBM), serta Pengumpul ikan dan Pedagang ikan. Secara jelas dapat dilihat pada Tabel 1. 
Tabel 1. Jumlah Bantuan PEMP yang Disalurkan di Kabupaten Maluku Tenggara 2001-2005

\begin{tabular}{cllc}
\hline Tahun & Jenis Usaha KMP & $\begin{array}{c}\text { Besarnya Bantuan } \\
\text { yang Diterima }\end{array}$ & $\begin{array}{c}\text { Jenis Bantuan yang } \\
\text { Diterima }\end{array}$ \\
\hline 2001 & Penangkapan & Rp 792.300.000,- & Penjaminan modal \\
2002 & Ikan, Kios, BBM & Rp 800.000.000,- & Penjaminan modal \\
2003 & Pengumpul Ikan & Rp 658.500.000,- & Penjaminan modal \\
2004 & Pedagang Ikan & Rp 556.370.000,- & Penjaminan modal \\
2005 & Pedagang Ikan & Rp 562.380.000,- & Penjaminan modal \\
\hline
\end{tabular}

Sumber: DKP (2006)

Program PEMP yang dilaksanakan di Kabupaten Maluku Tenggara sejak Tahun 2001-2005 tersebut diharapkan dapat memberikan hasil yang positif kepada masyarakat pesisir dan pulau-pulau kecil khususnya masyarakat nelayan. Adapun indikasi keberhasilan program PEMP tersebut akan terlihat dari meningkatnya kesejahteraan masyarakat pesisir, berfungsinya kelembagaan PEMP yang dibentuk, dan bergulirnya dana bantuan.

\section{Perumusan Masalah}

Program PEMP di Kabupaten Maluku Tenggara telah berjalan sejak tahun 2001. Kenyataan menunjukan bahwa dalam perjalanan pelaksanaan program PEMP tersebut ternyata belum terlihat adanya peningkatan kesejahteraan masyarakat pesisir khususnya kelompok nelayan yang ada di Kabupaten Maluku Tenggara, sehingga untuk sementara dapat dikatakan bahwa program PEMP yang dilaksanakan tersebut belum dapat membawa masyarakat pesisir yang ada di Kabupaten Maluku Tenggara menuju peningkatan taraf hidup mereka.

Program PEMP merupakan progam yang dibuat secara nasional yang diimplementasikan di beberapa daerah di Indonesia secara serentak. Padahal permasalahan yang dihadapi masyarakat pesisir antara satu daerah dengan daerah lain belum tentu sama. Masyarakat pesisir di Kabupaten Maluku Tenggara tentunya memiliki kelebihan dan kekurangan, 64 kekuatan dan kelemahan, peluang dan tantangan yang berbeda yang tidak bisa disamaratakan dengan daerah-daerah penerima program PEMP lainnya di Indonesia, sehingga kondisi tersebut mengakibatkan tidak optimalnya pencapaian tujuan program PEMP di Kabupaten Maluku Tenggara. Dengan demikian, untuk dapat mengelola dan memanfaatkan potensi sumberdaya alam pesisir dan laut yang ada di masing-masing daerah secara optimal, maka setiap daerah tentunya membutuhkan pendekatan program yang berbeda pula.

Permasalahannya kini adalah sejauh mana efektivitas pelaksanaan program PEMP di Kabupaten Maluku Tegggara dalam kaitannya dengan peningkatan kesejahteraan masyarakat itu sendiri. Untuk dapat menjawab permasalahan tersebut maka perlu dikaji kinerja dari Kelembagaan PEMP yang mencakup Dinas Kelautan dan Perikanan, Lembaga Ekonomi Pengembangan Pesisir Mikro Mitra Mina (LEPP-M3), Konsultan Manajemen (KM), Tenaga Pendamping Desa (TPD), Kelompok Masyarakat Pemanfaat (KMP) dan Kemitraan. Dimensi atau elemen kinerja ini penting karena merupakan hal yang dapat menjawab dinamika bekerjanya aspek-aspek dalam program PEMP, seperti input, proses dan outputnya. Hal ini sangat penting karena dari hasil kajian tersebut, berbagai program antar bidang diharapkan dapat diintegrasikan dan disinergikan menjadi suatu kebijakan baru untuk mendukung pelaksanaan program PEMP pada waktu mendatang. 


\section{Tujuan Penelitian}

Tujuan umum dari penelitan ini adalah untuk merumuskan strategi peningkatan mutu pelaksanaan program PEMP dalam upaya peningkatan kesejahteraan masyarakat pesisir di Kabupaten Maluku Tenggara. Adapun tujuan khusus dari penelitian ini adalah:

1. Mengidentifikasi elemen kinerja yang berpengaruh terhadap pelaksanaan program PEMP di Kabupaten Maluku Tenggara.

2. Mengevaluasi status keberlanjutan dari pelaksanaan program PEMP di Kabupaten Maluku Tenggara.

3. Merumuskan strategi kebijakan peningkatan mutu program PEMP di Maluku Tenggara.

\section{TINJAUAN PUSTAKA}

\section{Penelitian Terdahulu Terkait Program PEMP}

Secara umum, PEMP bertujuan untuk meningkatkan kesejahteraan masyarakat pesisir melalui pengembangan kegiatan ekonomi, peningkatan kualitas sumberdaya manusia dan penguatan kelembagaan sosial ekonomi dengan mendayagunakan sumberdaya perikanan dan kelautan secara optimal dan berkelanjutan (DKP, 2003). Penelitian tentang PEMP telah dilakukan oleh Khasanahturodhiyah (2002) di Kecamatan Wonokerto Kabupaten Pekalongan-Jawa Tengah. Pada penelitian ini, digunakan istilah KUB (Kelompok Usaha Bersama) untuk kelompok pemanfaat dana ekonomi produktif program PEMP, sedangkan pada struktur kelembagaan PEMP kelompok tersebut dikenal dengan istilah KMP (Kelompok Masyarakat Pemanfaat), maka dalam penulisan hasil penelitian ini digunakan istilah KMP. Pada penelitian ini juga diukur tingkat partisipasi peserta program PEMP dengan indikator yang digunakan adalah (1) kemauan masyarakat untuk ikut menanggung biaya pembangunan baik berupa waktu maupun tenaga dalam melaksanakan program PEMP, (2) hak masyarakat untuk ikut menentukan arah dan tujuan program yang dilaksanakan di Kecamatan Wonokerto Kabupaten Pekalongan, dan (3) kemauan masyarakat untuk melestarikan dan mengembangkan hasil program (Khasanaturodhiyah, 2002).

Penelitian Cahyadinata (2005) menyebutkan bahwa DEP PEMP di Kota Bengkulu belum mampu meningkatkan skala usaha masyarakat dan masih ada anggota KMP yang tidak berusia produktif, tidak memiliki pengalaman dan tidak memiliki hari kerja sehingga pengembalian pinjaman hanya 21 persen dari DEP dan bunga serta perguliran DEP hanya 10 persen dari pengembalian. Akibat tingkat pengembalian yang rendah, LEPP-M3 dan Mitra Kelurahan tidak memiliki dana operasional yang cukup untuk menjalankan tugasnya. Meskipun demikian, DEP PEMP yang diterima oleh anggota KMP dapat meningkatkan pendapatan yang diindikasikan oleh berpengaruh nyatanya jumlah pinjaman terhadap pendapatan.

\section{Konsep Masyarakat Pesisir}

Menurut Muluk (1996) klasifikasi masyarakat dapat dibedakan berdasarkan sifat mereka bermukim. Dengan kombinasi kiteria itu, masyarakat wilayah pesisir dapat dibagi kedalam: (a) Masyarakat nelayan, (b) masyarakat petani dan nelayan, (c) masyarakat petani (d) masyarakat pengumpul atau penjarah (collector, foreger), (e) masyarakat perkotaan dan perindustrian, dan (f) masyarakat tidak menetap /sementara.

Dalam konteks masyarakat menurut Satria (2002) yaitu masyarakat desa terisolisasi (masyarakat pulau kecil). Sehingga, masyarakat pesisir adalah masyarakat yang tinggal di wilayah pesisir baik sebagai nelayan, pengolah maupun bakul/pedagang ikan dalam kegiatan usaha perikanan. 


\section{Pemanfaatan Sumberdaya Perikanan}

Sumberdaya perikanan bukan satusatunya manfaat yang dapat diperoleh dari pengelolaan laut nasional. Laut juga memiliki fungsi penyedia produksi dan jasa bagi sektor-sektor transportasi, pertambangan mineral, pariwisata, pertahanan dan keamanan, serta produksi energi. Namun demikian, sebagai sebuah sistem, sumberdaya perikanan dapat dijadikan indikator yang baik bagi pengelolaan laut (Dahuri, 2004).

Sementara itu, dalam hal struktur pengelolaan, Hanna (1999) mengindentifikasi bahwa tidak ada bentuk terbaik dari struktur pengelolaan sumberdaya perikanan. Selalu ada kesenjangan (trade-offs) antara stabilitas dan fleksibilitas, antara otoritas dan keterwakilan, antara sosial dan individu, dan lain sebagainya. Dalam teori kebijakan, fungsi utama dari struktur pengelolaan sumberdaya perikanan adalah adanya stabilitas dan konsistensi dari pengambilan keputusan ketika sistem atau kondisi senatiasa harus adaptif terhadap perubahan (Nohria and Gulati, 1994).

Seperti yang telah diidentifikasi oleh Charles (2001), paling tidak ada dua makna dalam hal ini, yaitu pertama, bahwa sumberdaya perikanan yang tidak tak terbatas ini diakses oleh hampir semua kapal yang tidak terbatas (laissez-faire) yang diyakini akan menghasilkan kerusakan sumberdaya dan masalah ekonomi. Makna kedua adalah bahwa tidak ada kontrol terhadap akses kapal namun terdapat pengaturan terhadap hasil tangkapan.

\section{Kerangka Pemikiran}

Kabupaten Maluku Tenggara merupakan salah satu kabupaten kepulauan di Provinsi Maluku yang terdiri dari Kecamatan Kei Kecil (termasuk Kei Kecil Barat, Kei Kecil Timur, Dullah Utara, dan
Kecamatan Pulau-pulau Kur dengan luas $33 \mathrm{~km}^{2}$, Kecamatan Tayando-Tam dengan luas $133 \mathrm{~km}^{2}$, Kecamatan Kei Besar dengan luas $277 \mathrm{~km}^{2}$, Kecamatan Kei Besar Timur dengan luas $142 \mathrm{~km}^{2}$, dan Kei Besar Selatan dengan luas $162 \mathrm{~km}^{2}$, dengan demikian total luas daratan Kabupaten Maluku Tenggara adalah 4.049 $\mathrm{km}^{2}$. Sedangkan luas wilayah laut secara keseluruhan adalah $30.772,4 \mathrm{~km}^{2}$. Pada tahun 2006, produksi perikanan tangkap yang dihasilkan keenam kecamatan tersebut adalah sebesar 158.629,2 ton dengan total nilai produksi sebesar $\mathrm{Rp}$ 761.217.270,- (DKP Kabupaten Maluku Tenggara, 2007).

Besarnya potensi sumberdaya perikanan dan kelautan di Kabupaten Maluku Tenggara belum mampu mengangkat kehidupan ekonomi masyarakat pesisirnya. Kegiatan-kegiatan pemanfaatan sumberdaya perikanan kelautan ini bukan semata- mata terkendala masalah pembiayaan/dana tetapi juga mencakup faktor sumberdaya manusia/nelayan yang tidak terampil menggunakan teknologi penangkapan ikan serta jumlah armada yang masih sedikit. Sejak terpilih sebagai daerah penerima dana program PEMP pada tahun 2001, Pemerintah Kabupaten Maluku Tenggara dalam hal ini Dinas Kelautan dan Perikanan menyalurkan dana program PEMP dengan penekanan pada penanggulangan masalah setempat, oleh karena itu kucuran dana difokuskan pada pembelian/pembuatan kapal penangkap ikan. Sebagian lain dimanfaatkan sebagai modal usaha dan pembelian alat penangkap ikan baru.

Penerapan program PEMP di Kabupaten Maluku Tenggara yang mengacu program PEMP secara nasional ini apakah sudah sesuai dengan kondisi sumberdaya alam dan kondisi faktual yang ada di lapangan. Yang paling penting sebenarnya dalam menjalankan program PEMP adalah strategi yang tepat sesuai dengan kondisi riil Kabupaten Maluku 
Tenggara. Kerangka pendekatan studi yang digunakan dalam penelitian ini seperti terlihat pada Gambar 1.

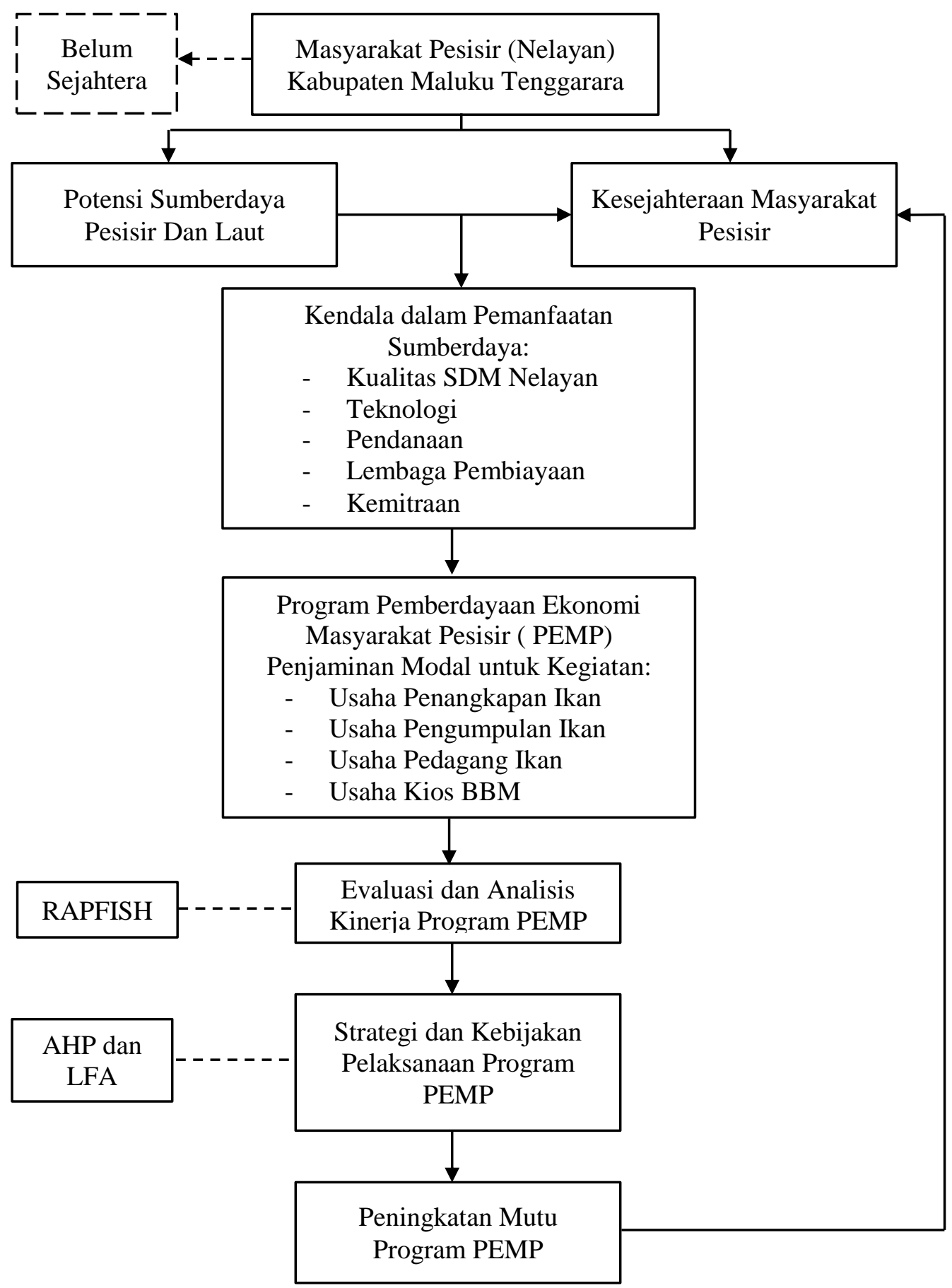

Gambar 1. Kerangka Pemikiran Penelitian

\section{METODE PENELITIAN}

\section{Lokasi dan Waktu Penelitian}

Lokasi penelitian adalah di wilayah administratif Kabupaten Maluku Tenggara
-Provinsi Maluku yang menerima program PEMP yaitu di Kecamatan Kei Kecil. Kecamatan ini dipilih sebagai lokasi penelitian karena dari beberapa kecamatan lainnya yang ada di Kabupaten Maluku Tenggara, kecamatan ini yang secara rutin dan paling banyak mendapat bantuan 
melalui program PEMP sejak tahun 20012006. Waktu penelitian adalah selama tiga bulan mulai dari bulan Oktober hingga bulan Desember 2008.

\section{Jenis dan Sumber Data}

Dalam penelitian ini ada dua jenis data yang dikumpulkan, yaitu data primer dan data sekunder. Data Primer dikumpulkan dari seluruh stakeholders yang menjadi sasaran evaluasi secara langsung. Proses untuk mendapatkan data primer ini melalui teknik wawancara terhadap responden dengan menggunakan kuesioner dan observasi langsung ke lapangan.

Data sekunder berupa dokumen atau referensi yang relevan dengan program PEMP seperti Laporan Keuangan LEPP-M3, kelengkapan administrasi lembaga, data statistik perikanan Kabupaten Maluku Tenggara serta kondisi geografis, demografis dan sosial ekonomi masyarakat yang didapat dari instansi pemerintah setempat.

\section{Metode Analisis}

Untuk mengetahui kondisi sosial, ekonomi dan budaya masyarakat pesisir dalam memanfaatkan sumberdaya wilayah pesisir dilakukan analisis deskriptif terhadap data primer yang diperoleh melalui pengamatan lapangan dan wawancara maupun data sekunder yang diperoleh dari instansi terkait. Demikian pula kondisi dan potensi sumber daya alam dianalisis secara deskriptif.

Metode yang digunakan untuk mengevaluasi status keberlanjutan adalah metode Rapid Appraisal for Fisheries (RAPFISH) yang dimodifikasi sesuai dengan kebutuhan kegiatan evaluasi kinerja komprehensif program PEMP. RAPFISH adalah teknik untuk mengevaluasi sumberdaya (Perikanan) secara kompeherensif berdasarkan atribut/indikator yang mudah untuk di scoring (Fauzi, 2005). Multi-dimensional
Scalling (MDS) sebagai uji statistik dalam RAPFISH adalah untuk mengetahui gambaran kinerja pelaksanaan program PEMP berdasarkan elemen kinerja yang di evaluasi.

\section{Metode Analytical Hierarch Process (AHP)}

Perancangan strategik dilakukan dengan menggunakan Analytical Hierarchy Process (AHP) atau Proses Hirarki Analitik (PHA) atau Analisis Jenjang Keputusan (AJK). AHP adalah suatu pendekatan yang biasanya digunakan untuk menganalisis kebijakan pembangunan dan/atau untuk memecahkan konflik kepentingan diantara para pemangku kepentingan (stakeholders). AHP pada dasarnya didesain untuk menangkap secara rasional persepsi orang yang berhubungan sangat erat dengan permasalahan tertentu melalui prosedur yang di desain untuk sampai pada suatu skala preferensi diantara berbagai set alternatif.

Saaty (1991) mengemukakan bahwa tahapan dalam analisis data sebagai berikut: (1) identifikasi sistem, (2) penyusunan struktur hirarki, (3) membuat matriks perbandingan/komparasi berpasangan (pairwise comparison), (4) menghitung matriks pendapat individu, (5) menghitung pendapat gabungan, (6) pengolahan horisontal, (7) pengolahan vertikal, dan (8) revisi pendapat.

\section{Metode Logical Framework Approach (LFA)}

Perancangan program dilakukan dengan menggunakan metode Logical Framework Approach (LFA). Pemilihan metode ini didasarkan pada pemikiran bahwa metode ini dapat digunakan untuk menganalisis masalah yang terlebih dahulu dianalisis dan ditetapkan masalah pokok dan masalah prioritas. Dalam hal ini metode LFA lebih aplikatif untuk dilaksanakan dalam upaya mengatasi dampak yang timbul dan mampu 
mengakomodir sebagian keinginan masyarakat.

Syaukat (2007) mengemukakan bahwa metode ini memiliki spesifik yaitu:

1. Menggunakan teknik visualisasi yang mampu membantu meningkatkan efisiensi dan efektivitas proses perencanaan dan pengelolaan program.

2. Merumuskan tujuan-tujuan secara jelas sehingga ikut mendorong tercapainya pengambilan keputusan saat ada pendapat dan harapan berbeda dari stakeholders.

3. Menyusun informasi secara sistematik.

4. Menghasilkan sebuah rancangan program yang konsisten dan realitis.

5. Menyajikan ringkasan rencana program pada satu halaman.

\section{HASIL DAN PEMBAHASAN}

\section{Kinerja Dan Status Keberlanjutan Pelaksanaan Program PEMP}

Dalam penelitian ini, alat analisis yang digunakan untuk mengevaluasi kinerja dan status keberlanjutan dari pelaksanaan program PEMP di Kecamatan Kei Kecil Kabupaten Maluku Tenggara adalah dengan metode Multi Dimensional Scalling (MDS) dan Rapid Appraisal for Fisheries Status (RAPFISH). Metode RAPFISH digunakan untuk menentukan posisi relatif dari setiap atribut pada elemen kinerja program PEMP terhadap keberhasilan (good) dan kegagalan (bad). Metode ini didasarkan pada hasil MDS dari kinerja pelaksanaan Program PEMP di Kecamatan Kei Kecil - Kabupaten Maluku Tenggara dimana mencakup lima elemen kinerja yang berpengaruh terhadap keberhasilan program PEMP, yaitu: (1) Kelembagaan program PEMP, (2) Pengelolaan LEPP-M3, (3) Kapasitas Pemanfaat Program, (4) Kemitraan, dan
(5) Persepsi Pemangku Kepentingan (stakeholders). Data untuk analisis ini diperoleh dari kuesioner yang diedarkan kepada pihak-pihak yang terlibat dalam pelaksanaan program PEMP.

Nilai MDS adalah dalam bentuk skoring mulai dari angka 0-100 yang dibagi dalam tiga kategori, yaitu (1) kinerja dikatakan "baik" apabila nilai elemen kinerja masuk dalam interval 0-33, (2) kinerja dikatakan "cukup baik" apabila nilai elemen kinerja masuk dalam interval 34-66, dan (3) kinerja dikatakan "buruk" apabila nilai elemen kinerja masuk dalam interval 67-100. Nilai yang diperoleh dari hasil MDS tersebut selanjutnya digunakan pada metode RAPFISH untuk mengetahui status keberlanjutan dari pelaksanaan program PEMP di Kecamatan Kei Kecil Kabupaten Maluku Tenggara.

Hasil analisis pada metode RAPFISH dibagi dalam lima kategori, yaitu (1) status keberlanjutan dikatakan "sangat baik" apabila nilai elemen kinerja masuk dalam interval 0-20, (2) status keberlanjutan dikatakan "baik" apabila nilai elemen kinerja masuk dalam interval >20-40, (3) status keberlanjutan dikatakan "cukup" apabila nilai elemen kinerja masuk dalam interval >40-60, (4) status keberlanjutan dikatakan "buruk" apabila nilai elemen kinerja masuk dalam interval >60-80, dan (5) status keberlanjutan dikatakan "sangat buruk" apabila nilai elemen kinerja masuk dalam interval $>80$ 100. Apabila nilai dari hasil analisis semakin mendekati 0 menunjukkan status keberlanjutannya semakin baik, begitu pula sebaliknya apabila nilai dari hasil analisis semakin mendekati 100 menunjukkan status keberlanjutannya semakin buruk. Selanjutnya, rekapitulasi nilai elemen kinerja dan status keberlanjutan kelima elemen kinerja program PEMP dapat dilihat pada Tabel 2. 
Tabel 2. Rekapitulasi Nilai Elemen Kinerja Program PEMP

\begin{tabular}{lcc}
\hline \multicolumn{1}{c}{ Elemen Kinerja Program PEMP } & Nilai & Kategori \\
\hline Kelembagaan PEMP & 52,95 & Cukup \\
Pengelolaan LEPP-M3 & 25,29 & Baik \\
Kapasitas Pemanfaat & 69,19 & Buruk \\
Kemitraan & 72,89 & Buruk \\
Pemangku Kepentingan & 75,08 & Buruk \\
\hline \multicolumn{1}{c}{ Rata-rata } & 59,08 & Cukup \\
\hline
\end{tabular}

Dari data pada Tabel 2 dan dengan mengacu pada rentang nilai skoring terlihat bahwa berdasarkan hasil analisis RAPFISH dari tiap elemen kinerja, ternyata elemen kinerja Kelembagaan PEMP (52,95) menunjukan status keberlanjutannya "cukup", kemudian elemen kinerja Pengelolaan LEPP-M3 $(25,29)$ menunjukan status keberlanjutannya "baik", sedangkan elemen kinerja Kapasitas Pemanfaat $(69,19)$, Kemitraan $(72,89)$, dan Pemangku Kepentingan $(75,08)$ menunjukkan status keberlanjutannya "buruk".

Dengan demikian berdasarkan nilai analisis RAPFISH tersebut diatas, secara keseluruhan terlihat bahwa pelaksanaan Program PEMP di Kecamatan Kei KecilKabupaten Maluku Tenggara menunjukan nilai rata-rata 59,08. Oleh karena nilai ratarata dari kelima elemen kinerja Program PEMP tersebut berada pada rentang nilai $>40-60$, maka status keberlanjutannya berada pada kategori "cukup".

\section{Skala Prioritas Alternatif Kebijakan Peningkatan Mutu Program PEMP}

Penentuan alternatif kebijakan peningkatan mutu pelaksanaan program PEMP dilakukan dengan menggunakan Analisis Hirarki Proses (AHP) dimana dengan metode ini diharapkan dapat menangkap persepsi atau pandangan stakeholders tentang pelaksanaan program PEMP di Kabupaten Maluku Tenggara. Persepsi atau pandangan stakeholders tersebut diserap melalui pengisian kuesioner yang diberikan kepada setiap responden, prinsip penilaian AHP adalah membandingkan tingkat kepentingan prioritas antara satu elemen dengan elemen lainnya yang berada pada tingkatan atau level yang sama berdasarkan pertimbangan tertentu.

Struktur yang dibangun terdiri dari tiga tingkatan keputusan yaitu: (1) Tujuan (warna kuning), (2) Kriteria (warna biru), dan (3) Alternatif kebjakan (warna hijau) sebagaimana terlihat pada Gambar 2.

Tujuan yang ingin dicapai dengan menggunakan model AHP adalah merumuskan "Strategi Kebijakan Peningkatan Mutu Pelaksanaan Program PEMP" sehingga kepentingan antar lembaga dalam kelembagaan PEMP dapat dilaksanakan secara terencana, terpadu, terarah dan sistematis berdasarkan skala prioritas. 


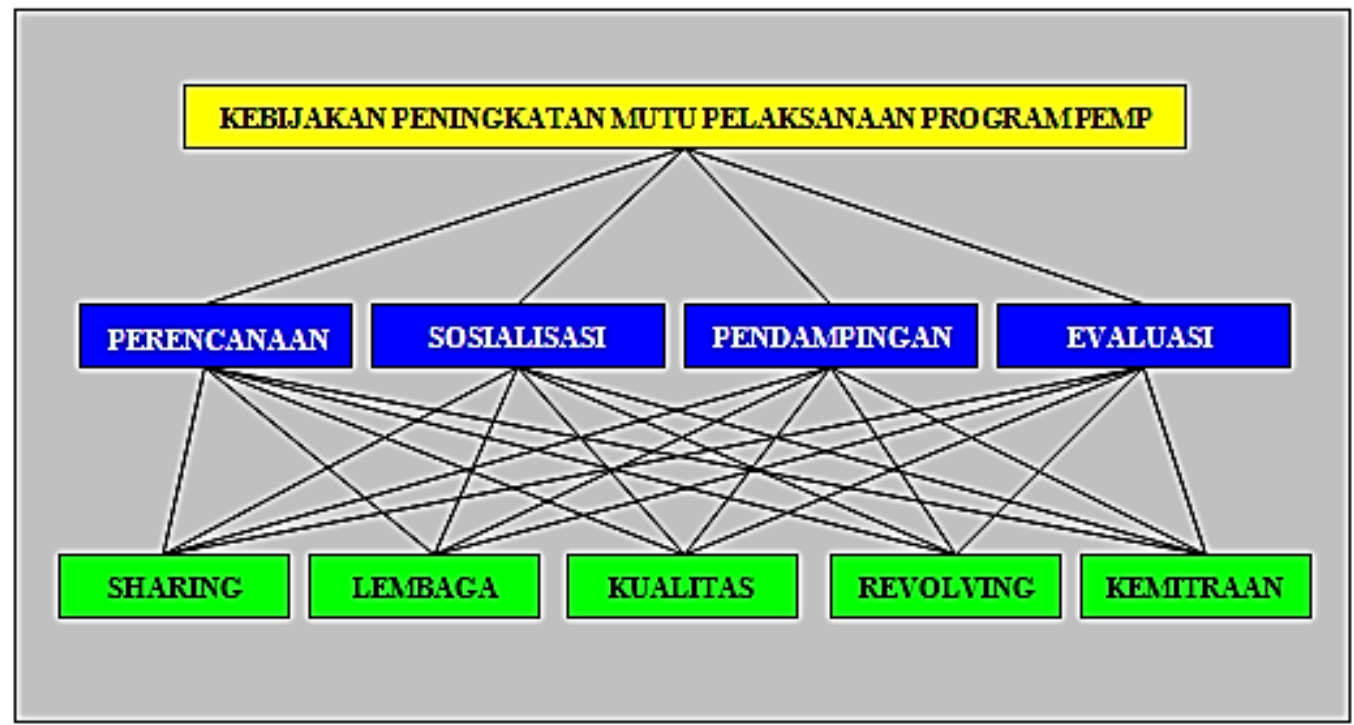

Gambar 2. Struktur Mutu Pelaksanaan Program PEMP

Untuk dapat mencapai tujuan diatas yaitu merumuskan Strategi kebijakan peningkatan mutu pelaksanaan program PEMP, terdapat empat kriteria yang harus diperhatikan yaitu (1) aspek perencanaan program PEMP berbasis masyarakat, (2) aspek sosialisasi program PEMP, (3) aspek pelaksanaan pendampingan program

Tabel 3. Skala Prioritas Kriteria

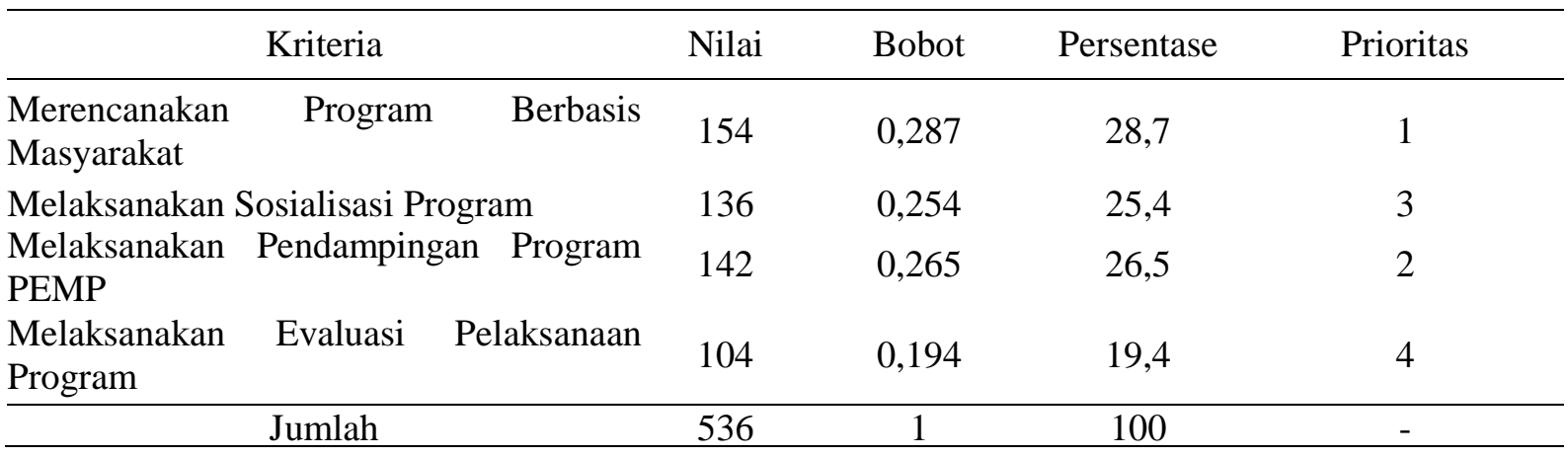

Dari Tabel 3 terlihat bahwa secara hirarki, kriteria yang paling penting menurut responden dalam upaya mencapai tujuan diatas adalah perencanaan program PEMP berbasis masyarakat dengan jumlah nilai $154 \quad(28,7 \%)$. Kriteria yang merupakan prioritas kedua adalah pelaksanaan pendampingan program PEMP dengan jumlah nilai 142 (26,5\%). Kriteria yang merupakan prioritas ketiga adalah sosialisasi program PEMP dengan jumlah nilai $136(25,4 \%)$. Kriteria yang merupakan urutan terakhir adalah evaluasi
PEMP, dan (4) aspek evaluasi pelaksanaan program PEMP. Hasil analisis pendapat gabungan rensponden yang diolah dengan Expert Choice 9.5 menunjukan besarnya kontribusi yang diberikan oleh masingmasing kriteria terhadap tujuan yang ingin dicapai seperti terlihat pada Tabel 3.

pelaksanaan program PEMP dengan jumlah nilai $104(19,4 \%)$.

Dari keempat tujuan kriteria diatas dirumuskan lima alternatif strategi kebijakan pilihan yang dapat dilakukan oleh Pemerintah Daerah Kabupaten Maluku Tenggara, kelima alternatif tersebut adalah (1) Strategi kebijakan sharing dana dari Pemerintah Kabupaten Maluku Tenggara, (2) Strategi kebijakan penguatan kelembagaan PEMP dan SDM, (3) Strategi kebijakan peningkatan kualitas partisipasi masyarakat, (4) Strategi 
kebijakan penataan sistem pengembalian dana bergulir, dan (5) Strategi kebijakan pengembangan kemitraan.

Berdasarkan hasil analisis pendapat gabungan responden, diketahui bahwa prioritas alternatif kebijakan yang harus diperhatikan oleh Dinas Kelautan dan Perikanan Kabupaten Maluku Tenggara dalam upaya peningkatan mutu pelaksanaan program PEMP, yang merupakan sintesis dari pendapat seluruh responden seperti terlihat pada Tabel 4 .

Tabel 4. Skala Prioritas Strategi Kebijakan Pilihan

\begin{tabular}{|c|c|c|c|c|}
\hline Alternatif Pengembangan & Nilai & Bobot & Persentase & Prioritas \\
\hline Penguatan Kelembagaan PEMP dan SDM & 614 & 0,214 & 21,4 & 1 \\
\hline $\begin{array}{l}\text { Sharing dana dari Pemerintah Kabupaten Maluku } \\
\text { Tenggara }\end{array}$ & 588 & 0,206 & 20,6 & 2 \\
\hline Pengembangan Kemitraan & 566 & 0,200 & 20,0 & 3 \\
\hline $\begin{array}{l}\text { Penataan sistem pengembalian dana bergulir } \\
\text { (revolving) }\end{array}$ & 544 & 0,192 & 19,2 & 4 \\
\hline Peningkatan kualitas partisipasi masyarakat & 530 & 0,188 & 18,8 & 5 \\
\hline
\end{tabular}

Dari Tabel 4 terlihat bahwa berdasarkan keempat kriteria tersebut, penguatan kelembagaan PEMP dan SDM menempati urutan pertama dengan nilai 614 dan bobot 0,214 (21,4\%), kemudian diikuti oleh sharing dana dari Pemerintah Kabupaten Maluku Tenggara dengan nilai 588 dan bobot 0,206 (20,6\%), pengembangan kemitraan dengan nilai 566 dan bobot $0,20(20,0 \%)$, penataan sistem pengembalian dana bergulir (revolving) dengan nilai 544 dan bobot 0,192 (19,2\%), dan urutan terakhir adalah peningkatan kualitas partisipasi masyarakat dengan nilai 530 dan bobot $0,188(18,8 \%)$. Dengan demikian total persentase seluruh kriteria terhadap tujuan yang ingin dicapai untuk kelima alternatif kebijakan tersebut adalah sebesar $100 \%$.

\section{Rancangan Program Peningkatan Mutu Program PEMP}

Program PEMP yang dilaksanakan di Kabupaten Maluku Tenggara sejak Tahun 2001-2007 tersebut diharapkan dapat memberikan hasil yang positif kepada masyarakat pesisir dan pulau-pulau kecil khususnya masyarakat nelayan. Adapun indikasi keberhasilan program PEMP tersebut akan terlihat dari meningkatnya kesejahteraan masyarakat pesisir, berfungsinya kelembagaan PEMP yang dibentuk, dan bergulirnya DEP. Namun sejauh ini, dampak dari pelaksanaan program PEMP tersebut terlihat belum dapat meningkatkan kesejahteraan masyarakat pesisir setempat sebagaimana yang diharapkan, untuk itu dibutuhkan campur tangan Pemerintah Daerah Kabupaten Maluku Tenggara untuk membantu dengan berbagai strategi kebijakan lainnya sehingga apa yang diharapkan dari pelaksanaan program PEMP tersebut dapat tercapai. Oleh karena itu berdasarkan hasil kajian ini maka rancangan program strategi peningkatan mutu program PEMP di Kabupaten Maluku Tenggara (Tabel 5). 


\begin{tabular}{|c|c|c|c|c|}
\hline Program & Rencana Tindak & Pelaksana & Sasaran & Luaran \\
\hline $\begin{array}{l}\text { 1. Penguatan } \\
\text { kelembagaan } \\
\text { PEMP dan SDM }\end{array}$ & $\begin{array}{l}\text { - Rapat koordnasi dan } \\
\text { lokakarya } \\
\text { - Melanjutkan studi bagi } \\
\text { aparatur pengelola } \\
\text { program } \\
\text { - Pelatihan, kursus, } \\
\text { magang, studi banding } \\
\text { - Seleksi TPD } \\
\text { - Montoring dan evaluasi } \\
\text { - Melaksanakan sosialsasi }\end{array}$ & $\begin{array}{l}\text { Instansi Teknis } \\
\text { (DKP), KM, } \\
\text { LEPP-M3 }\end{array}$ & $\begin{array}{l}\text { Aparatur DKP, } \\
\text { Aparatur - } \\
\text { pengelola - } \\
\text { program, LEPP- } \\
\text { M3, KM, TPD, } \\
\text { KMP, Mitra }\end{array}$ & $\begin{array}{l}\text { Akses antar } \\
\text { kelembagaan, } \\
\text { kemandirian usaha, } \\
\text { peningkatan skala } \\
\text { usaha, peningkatan } \\
\text { pengetahuan. }\end{array}$ \\
\hline $\begin{array}{l}\text { 2. Sharing dana } \\
\text { dari PEMDA }\end{array}$ & Penetapan alokasi anggaran & PEMDA & $\begin{array}{l}\text { Fasilitasi, } \\
\text { koordinasi, } \\
\text { integrasi. }\end{array}$ & $\begin{array}{l}\text { Penguatan } \\
\text { kelembagaan }\end{array}$ \\
\hline $\begin{array}{l}\text { 3. Peningkatan } \\
\text { kualitas } \\
\text { partisipasi } \\
\text { masyarakat }\end{array}$ & $\begin{array}{l}\text { - Pengembangan SDM, } \\
\text { ekonomi dan sosial } \\
\text { budaya } \\
\text { - Peningkatan akses modal, } \\
\text { pasar, teknolgi, lembaga } \\
\text { ekonom serta kemitraan }\end{array}$ & $\begin{array}{l}\text { Instansi Teknis } \\
\text { dalam hal ini } \\
\text { DKP }\end{array}$ & KMP & $\begin{array}{l}\text { Peningkatan } \\
\text { pengetahuan, } \\
\text { perubahan sikap, } \\
\text { kemandran usaha }\end{array}$ \\
\hline $\begin{array}{l}\text { 4. Penataan sistem } \\
\text { pengembalan } \\
\text { dana bergulir }\end{array}$ & $\begin{array}{l}\text { Pemberlakuan aturan kredit } \\
\text { berupa agunan, kemudahan } \\
\text { angsuran sesuai } \\
\text { kemampuan nelayan yakni } \\
\text { per hari atau perminggu }\end{array}$ & LEPP-M3 & KMP & $\begin{array}{l}\text { Mengatasi kredit } \\
\text { macet }\end{array}$ \\
\hline $\begin{array}{l}\text { 5. Pengembangan } \\
\text { kemitraan }\end{array}$ & $\begin{array}{l}\text { Workshop, Lokakarya yang } \\
\text { melibatkan semua } \\
\text { pemangku kepentingan } \\
\text { (stakeholders) }\end{array}$ & $\begin{array}{l}\text { Instansi } \\
\text { Teknis (DKP). }\end{array}$ & $\begin{array}{l}\text { Eksekutif, } \\
\text { legislatif, swasta, } \\
\text { perbankan }\end{array}$ & $\begin{array}{l}\text { - Peningkaan } \\
\text { partisipasi } \\
\text { - Penguatan modal }\end{array}$ \\
\hline
\end{tabular}

\section{KESIMPULAN DAN SARAN}

\section{Kesimpulan}

1. Berdasarkan rata-rata nilai total lima elemen kinerja program PEMP hasil analisis Multi Dimentional Scalling (MDS) menunjukkan bahwa kinerja program secara menyuluruh mencapai nilai 59,08 atau tergolong "cukup" dengan demikian maka status keberlanjutanya pun berada pada kategori "cukup". Hal ini berarti kinerja program PEMP telah berjalan sesuai dengan tujuan dan sasaran yang ditetapkan, namun pada masa mendatang pelaksanaan program PEMP masih perlu disempurnakan dan diintensifkan.

2. Kelembagaan program PEMP belum berjalan sesuai dengan apa yang diharapkan dalam tujuan dan sasaran dari program PEMP itu sendiri. Masih ada beberapa aparat pengelola program PEM yang belum memahami tugas pokok dan fungsinya serta belum berperan secara aktif dalam mengawal pelaksanaan program PEMP di lapangan, Pengelolaan Koperasi LEPP-M3 sudah mulai menguat, pengelola koperasi LEPPM3 sudah mulai memahami tugas pokok dan fungsinya. Pemahaman tupoksi ini merupakan modal kuat dalam pelaksanaan mekanisme dan prosedur program yang baik dan benar.

3. Leverage Analysis dalam RAPFISH menunjukkan bahwa status kinerja program PEMP per elemen yang dievaluasi tersebut sangat dipengaruhi oleh : (a) berjalan atau tidaknya peran dan fungsi TPD, Koperasi LEPP-M3 dan bank pelaksana didalam kelembagaan program PEMP, (b) 
berjalan atau tidaknya sistem dan mekanisme pengelolaan DEP yang mendukung baiknya kinerja keuangan Koperasi LEPP-M3, (c) ada atau tidaknya perubahan pendapatan bagi KMP/Individu dan bertambahnya nilai manfaat terhadap program PEMP, (d) terwujud atau tidaknya sinergitas pemangku kepentingan program untuk bahu-membahu mendukung pelaksanaan program, dan (e) ada atau tidaknya pemahaman yang baik dari kelompok masyarakat pemanfaat terhadap substansi, mekanisme, dan kelembagaan program PEMP yang tercermin pada tingkat partisipasi masyarakat pada pelaksanaan program PEMP.

4. Berdasarkan Proses Hirarki Analitik (PHA) dalam penentuan alternatif strategi dan kebijakan peningkatan mutu pelaksanaan program PEMP, maka struktur yang dibangun terdiri dari tiga tingkatan keputusan yaitu (1) Tujuan, (2) Kriteria dan (3) Alternatif. Tujuan yang ingin dicapai adalah merumuskan Strategi Kebijakan Peningkatan Mutu Pelaksanaan Program PEMP. Untuk dapat mencapai tujuan diatas, terdapat empat kriteria yang harus diperhatikan yaitu (1) aspek perencanaan program PEMP berbasis masyarakat, (2) aspek sosialisasi program PEMP, (3) aspek pelaksanaan pendampingan program PEMP, dan (4) aspek evaluasi pelaksanaan program PEMP. Dari keempat kriteria diatas selanjutnya dapat dirumuskan lima alternatif strategi kebijakan yang seharusnya dilakukan oleh Pemerintah Daerah Kabupaten Maluku Tenggara (dalam hal ini Dinas Kelautan dan Perikanan) dalam memanfaatkan program PEMP yang merupakan program Pemerintah (dalam hal ini Departemen Kelautan dan Perikanan Republik Indonesia), yaitu (1) Strategi kebijakan sharing dana dari Pemerintah Kabupaten
Maluku Tenggara, (2) Strategi kebijakan penguatan kelembagaan PEMP dan SDM, (3) Strategi kebijakan peningkatan kualitas partisipasi masyarakat, (4) Strategi kebijakan penataan sistem pengembalian dana bergulir, dan (5) Strategi kebijakan pengembangan kemitraan.

\section{Saran}

1. Untuk memaksimalkan kedudukan dan peran Kelembagaan dalam menunjang pelaksanaan program PEMP perlu ditingkatkan partisipasi segenap lapisan masyarakat sehingga menciptakan dukungan sumberdaya yang luas untuk mencapai tujuan program.

2. Dalam upaya mengoptimalkan kinerja dan pengelolaan Koperasi LEPP-M3 diperlukan peningkatan kualitas SDM, rumusan dan mekanisme kerja sebagai dasar menjalankan koperasi untuk menghindari konflik kepentingan dan kewenangan, pengembangan model pengelolaan koperasi sesuai dengan karakteristik sosial-budaya dan kebutuhan masyarakat pesisir, penerapan manajemen keuangan dan pelaporan yang baik, dan menyediakan biaya-biaya operasional yang memadai.

3. Perlu dibuatkan aturan yang bersifat detail dalam hal teknis pelaksanaan program PEMP oleh Dinas Kelautan dan Perikanan Kabupaten Maluku Tenggara berdasarkan Pedoman Umum (Pedum) program PEMP yang dikeluarkan oleh Departemen Kelautan dan Perikanan. 


\section{DAFTAR PUSTAKA}

Cahyadinata, I. 2005. Analisis Program Pemberdayaan Ekonomi Masyarakat Pesisir (PEMP) di Kota Bengkulu. Tesis Program Pascasarjana IPB. Bogor.

Charles, A.T. 2001. Sustainable Fishery Systems. Blackwell Sciences. London, UK.

Dahuri, R. 2004. Membangun Indonesia yang Maju, Makmur dan Mandiri Melalui Pembangunan Maritim. Makalah disampaikan pada Temu Nasional Visi dan Misi Maritim Indonesia dari Sudut Pandang Politik, Jakarta, 18 Februari 2004, Jakarta.

[DKP] Departemen Kelautan dan Perikanan. 2003. Pedoman Umum Program Pemberdayaan Ekonomi Masyarakat Pesisir Tahun 2003. Direktorat Pemberdayaan Masyarakat Pesisir, Ditjen P3K Departemen Kelautan dan Perikanan, Jakarta.

2006. Pedoman Umum Program Pemberdayaan Ekonomi Masyarakat Pesisir Tahun 2006. Direktorat Pemberdayaan Masyarakat Pesisir, Ditjen KP3K Departemen Kelautan dan Perikanan, Jakarta.

[DKP] Dinas Kelautan dan Perikanan Kabupaten Maluku Tenggara. 2006. Statistik Perikanan Kabupaten Maluku Tenggara Tahun 2005, Tual. 2007. Blue Print

Pembangunan Kelautan dan Perikanan Kabupaten Maluku Tenggara Tahun 2004-2008, Tual.

Hanna, S., 1999. Strengthening Governance of Ocean Fishery Resources. Ecological Economics Vol. 31.

Khasanaturodhiyah. ST. 2002. Kajian Partisipasi Peserta dan Kinerja Pengelolaan Program PEMP. Tesis Program Pascasarjana IPB. Bogor.
Muluk, C. 1996. Sistem Sosial Ekonomi dan Budaya Masyarakat Pesisir. Makalah Pelatihan Perencanaan dan Pengelolaan Wilayah Pesisir Secara Terpadu. Angkatan V. 16 April - 31 Agustus 1996. Bogor.

Nikijuluw, V.P.H. 2001. Populasi dan Sosial Ekonomi Masyarakat Pesisir serta Strategi Pemberdayaan Mereka dalam Konteks Pengelolaan Sumberdaya Pesisir Secara Terpadu. Makalah pada Pelatihan Pengelolaan Pesisir Terpadu, Proyek Pesisir, PKSPL, IPB. Hotel Permata, 29 Oktober 2001. Bogor.

Nohria, N and Gulati, R., 1994. Firms and Their Environments. In : Smelser, N.J. and Swedberg, R. (Eds). The Handbook of Economic Sociology. Princenton University Press. Pricenton, NJ.

Satria, A. 2002. Pengantar Sosiologi Masyarakat Pesisir. PT. Pustaka Cidesindo. Jakarta.

Satria, A. et, al. 2002. Menuju Desentralisasi Kelautan, Pusat Kajian Agraria IPB, Partnership for Governance Reform in Indonesia dan PT. Pustaka Cidesindo. Jakarta.

Sulistyowati, L. 2003. Analisis Kebijakan Pemberdayaan Masyarakat Dalam Pengelolaan Sumber Daya Alam Gugus Kepulauan (Studi kasus Kelurahan Pulau Kelapa dan Kelurahan Pulau Harapan Kecamatan Kepulauan Seribu Utara, Taman Nasional Laut Kepulauan Seribu. Disertasi Program Pascasarjana Institut Pertanian Bogor. 